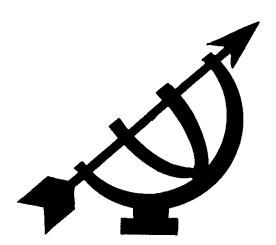

\title{
Some views of Xhosa women regarding the initiation of their sons
}

\author{
M.A. Venter \\ School of Education \\ University of South Africa \\ PRETORIA \\ E-mail:ventema@unisa.ac.za
}

\begin{abstract}
Some views of Xhosa women regarding the initiation of their sons
\end{abstract}

Notwithstanding attempts from the Eastern Cape Department of Health and other organisations to regulate the process of initiation, each year initiates still die or are mutilated. The challenge is to keep the boys safe without interfering with the traditional customs. It appears that women's voices are rarely heard on this issue.

Through a literature review the author attempts to understand the rite of initiation from a cultural perspective. The general meaning and specific usage of concepts such as 'culture', 'traditional', and 'masculinity' are explained, as well as how these concepts are used in the article. A questionnaire was designed and administered to establish the views of Xhosa women on the ritual of initiation.

On comparing these results with results from previous research, it shows a decline in the number of women who favour the traditional way of initiation without medical intervention. Although this indicates a shift in women's views, a conflict is evident, as there is still overwhelming agreement that traditional initiation is a prerequisite for becoming a man who is respected by his community. The empirical research indicates that although women are forbidden to take part in discussions on this subject, some women did take the liberty to express their opinions. 


\section{Opsomming}

\section{Xhosavroue se menings rakende die inisiasie van hulle seuns}

Ten spyte van pogings van die Oos-Kaapse Departement van Gesondheid en ander organisasies om die proses van inisiasie te reguleer, is daar jaarliks steeds seuns wat sterf of geskend word. Die uitdaging is om die seuns te beskerm sonder om met die tradisionele gebruike in te meng. Vroue se stemme word selde gehoor in gesprekke oor hierdie kwessie.

Deur middel van 'n literatuurstudie is gepoog om die rite van inisiasie vanuit 'n kulturele perspektief te verstaan. Die algemene betekenis en spesifieke gebruik van konsepte soos 'kultuur', 'tradisioneel' en 'manlikheid' word uitgeklaar en daar word verduidelik hoe hierdie konsepte in die artikel gebruik word. 'n Vraelys is opgestel en afgeneem om vas te stel wat die opinie van Xhosavroue ten opsigte van die rite van inisiasie is.

'n Vergelyking van hierdie navorsingsresultate met resultate wat voorheen verkry is, wys op 'n afname in die hoeveelheid vroue wat ten gunste is van tradisionele inisiasie sonder mediese intervensie. Alhoewel dit op ' $n$ verandering in die vroue se mening dui, dui dit tog op 'n teenstrydigheid, aangesien daar steeds 'n algemene ooreenstemming is dat tradisionele inisiasie 'n voorwaarde is vir 'n man om deur sy gemeenskap gerespekteer te word. Die empiriese navorsing toon dat sommige vroue wel die vrymoedigheid gehad het om hulle opinies te lug, alhoewel vroue verbied word om aan gesprekke oor hierdie saak deel te neem.

\section{Introduction}

In 2009 it was reported in the press that a 21-year-old young man was taking his parents to court regarding his constitutional rights. After he tried to compromise with the local headmen to have the procedure of circumcision done in hospital, he was abducted by his father and ten other men from his home in Masele Township near King William's Town, and subjected to circumcision against his will (Huisman, 2009:1).

Male initiation is an important and deeply-rooted custom of various ethnic groups in South Africa, especially of the amaXhosa. It serves as a doorway through which the Xhosa adolescent male must step in order to become a respected member of society, or as it is called among the amaXhosa, to attain manhood. Obtaining this status bestows rights, privileges and obligations on the individual concerned (Mtuze, 2008:119). 
Every year there are reports in the media about amputations, mutilations and mortality among male initiates. The initiation season of 2010 started out with eleven deaths being reported on 14 June 2010. Teams were subsequently sent out by the Department of Health to control the process. On 29 June the mortality rate was 33 (Anon., 2010a:2) and by 13 July, 41 boys had died (Anon., 2010b: 4). Consequently, initiation schools in Pondoland were temporarily closed by the Department of Health. Reasons for the apparent increase in deaths and mutilations are unclear. Official circumcision task teams operate from hospitals in the Eastern Cape and organisations such as Isikololuntu have been established. Isikololuntu (custom of the people) is an association of traditional surgeons who uphold clean, yet traditional practice, by regulating the practice (Kretzman, 2000:27-29).

My first awareness of the implications of the rite of initiation and the impact it has on the lives of initiates and their families, was through my students' assignments. During workshop discussions some students share their concern about the mortality rate, but others vehemently defend the ritual - even if it may be to the detriment of the boys. Literature also reports on boys who "suffer severe emotional and spiritual confusion if they are not allowed to undergo this traditional practice" (Tenge, 2006:3).

Research on the rite of initiation has been done from a wide range of perspectives. From a medical perspective, research was done by Meintjes (1998), Marck (1997), and Kretzman (2000). Research from a social perspective was done by Ntombana (2009), Magubane (1998), Ngxamngxa, (1968), Van Vuuren and De Jongh (1999), Lodewijckx and Syroit (1997), De la Harpe (2002), and Bottoman (2006). However, in this literature no quantitative research exists on the views of Xhosa women regarding initiation. The only study I could find was done among Xhosa women in 1987. In this study it was found that $98,5 \%$ of the women felt that traditional initiation practices for Xhosa boys should be retained (Steyn, 1987:163-174).

Geisler (1997:93-129) makes the following statement regarding male and female initiation:

The competition over what is and should be tradition, has largely been the prerogative of men, and it has been used by men to ensure their control over women and to circumscribe the scope of women's subordinated status and the single most important factor standing in the way of their emancipation. But 
African women have at times appeared as the custodians of tradition and thus the agents of their own subordination.

The position and role of women in society is a complex phenomenon with many variables. Geisler's statement implies that women play a role in their own subordination. In this article I demonstrate how the Xhosa woman is caught in a struggle between her allegiance to her culture, and her fear for the safety of her children.

The aim of the study was to determine the attitudes of Xhosa women towards their sons' initiation rites. A questionnaire was completed by 54 Xhosa women and one in-depth interview was held with a Xhosa woman. Recognising the complex nature of terms such as traditional, culture and manhood or masculinity, I explain the meaning of these terms from different perspectives and clarify how I utilise them in this article.

I argue that women do not only have the right to be involved in any matter concerning their children's physical and emotional well-being, but as legal guardians under the law, they are responsible to put their children's safety above any cultural custom or ritual.

\section{Theoretical framework}

\subsection{Process and symbolic meaning of initiation}

The concept of tradition is generally understood to refer to the handing down of opinions, principles, doctrines or customs from ancestors to posterity by means of oral communication. For the purposes of this article tradition refers to the habits or rituals which have been established through the ages among the amaXhosa.

Initiation is a ritual that is practised among various groups to incorporate a new member into the existing group, but it is practised more often when there are prominent or marked changes in the lives of individuals (Lodewijckx \& Syroit, 1997:275-300). It often requires seclusion, as well as certain ritual behaviour and prescriptions by the adult regarding certain aspects of the adult life. Often, and especially with boys, initiation contains a physical challenge that could serve as a test for masculinity (Berk, 2009:198; Ntombana, 2009:7384). For the Xhosa male, initiation serves as a movement or transition from boyhood (ubukhwenkwe) to manhood (ubudoda). The general meaning of masculinity relates to belonging to the male gender and showing manly characteristics. In this article, the women regarded masculinity as relating to being brave and determined, and 
showing qualities of leadership. They also added that it referred to the quality of high morality in men who acted courageously and boldly, and who were able to bear suffering.

Van Gennep (1960:71) identifies three phases in rites of passage, namely separation, transition and integration.

The phase of separation, which starts with preritual preparations, involves the appointment of a host, the building of the lodge, and the appointment of the functionaries, namely the incgibi (traditional surgeon) and the ikhankatha (traditional nurse). The evening before the initiation, a celebration takes place during which a goat is slaughtered for each boy. This celebration is attended by other boys and girls from the area. The boy must then eat the right shoulder of the goat (Meintjes, 1998:7). From this moment on the boy is considered to be an umkhwetha, or Xhosa initiate.

In the period of transition an umkhwetha is physically isolated and is considered - from a ritual viewpoint - as contaminated and thus dangerous to "normal" people, especially women or uninitiated men. The specific prescriptions with regard to clothes, food and movement are coupled with ritual washing, shaving and the smearing of the body with special white clay, circumcision, the slaughter of animals, physical challenges, ordeals, and the learning of a dialect of Xhosa or bush language known as hlonipha (Meintjes, 1998:8, 89). Mncube (1987:20) describes hlonipha as "one of the verbal avoidance customs". According to Xhosa tradition there is power in the spoken word or in certain behaviours. Hlonipha carries the meaning of avoiding a certain behaviour or saying something that might offend certain people or spiritual entities (Bongela, 2001:25). This means that a verbal act, such as calling out someone's name, may expose a person to magic or witchcraft. When the Xhosa boys are in seclusion, they are therefore not referred to by their usual names, but are called abakhwetha (initiates) to protect them. This custom was expanded to include a special vocabulary for the food they eat, objects around them, and it developed into a "language of avoidance" (Ngxamngxa, 1968:10).

For the circumcision operation the initiates sit on their blankets with their legs spread open. The ingcibi uses a spear, knife or scalpel to perform the circumcision. As soon as the boy has been circumcised the ingcibi tells him, Yithi uyindoda! ("Say you are a man!"), and the initiate replies, Ndiyindoda! ("I am a man!") (Meintjes, 1998:9). Immediately after the circumcision the leaves of a plant with haemostatic and astringent properties, Helichrysum pedunculare, are 
used as a wound dressing. A hide thong is then applied by winding it tightly around the penis from base to tip and then back to the base again, where it is tied to a separate thong which is around the initiate's waist. The boys are taken care of in the lodge or hut until the wounds have healed. During this time they receive practical and theoretical instruction and there is certain ritual behaviour, which they must perform while avoiding all ritual taboos (Marck, 1997:337360). During the healing period the drinking of water is restricted. Some researchers report that no water may be drunk for the first seven days (Lodewijckx \& Syroit, 1997:275-300; Meintjes 1998:9). In some cases a little water is allowed.

The coming out or integration into the community also takes place in phases. Towards the end of the transition phase, girls are allowed to visit the initiates as a part of the ritual. It is customary for initiates to perform a traditional dance to indicate their newly-acquired manhood in the presence of singing girls (Bottoman, 2006:31). There are also stick fights among the boys to determine the ranking between them. Before they return to the community, a ritual washing takes place in a river. The white clay or ash is washed and their hair is shaved. They return to the hut where their fathers and other dignitaries wait. The boys approach the group, chanting and with heads bowed in respect. The proud fathers then smear the boys' bodies with butter as a part of the ceremony, fit them with new penis sheathes, and cover them with clean blankets. While the boys face away from the hut, one of the fathers sets fire to it. The boys, who are now regarded as men, walk away without turning back, symbolically leaving behind their boyhood (De la Harpe, 2002:70-74).

\subsection{Medical and psychological complications of the initiation rite}

Meintjes (1998) reports on field work that was done from 1996 to 1997 in parts of the Eastern, Northern and Western Cape. This field work was done by medical doctors in cooperation with the Circumcision Task Team, which operates from the Cecilia Makiwane Hospital in Mdantsane. According to this research, the most common reasons for complications are ischaemia (starvation of blood supply), infection, gangrene and dehydration.

Ischaemia is caused by the hide thong being tied too tightly around the penis or by a thong that is too thin and cuts into the skin. It can also be caused by other tightly-bound cloth or elastic that cuts off the blood supply. When the blood supply is compromised it may lead to bacterial infection, which leads to more swelling that impedes 
the blood flow even more. This in turn may lead to sepsis, arterial thrombosis and ultimately to gangrene, which may necessitate partial or full penile amputation. Local infection in the circumcision wound can spread to the lymph nodes, which can lead to multiple organ failure. Further medical complications as observed by Meintjes (1998:26) are gangrene, sepsis and organ failure.

It has been found that initiates and amakhankatha sometimes do not wash their hands before applying dressings. Saliva is sometimes applied to the under-surface of the leaves that are used as dressings and often the leaves are rubbed against the sole of the foot before they are applied. Circumcision with one spear, knife or blade may lead to the transfer of sexually transmitted diseases, such as HIV and AIDS, gonorrhoea, syphilis, lymphogranuloma venereum, and other illnesses such as Hepatitis B (Walque, 2006:110).

A further complicating factor may be that the spear with which the circumcision is executed is blunt, which may lead to incomplete circumcisions, lacerations of the glans, injury to the urethra, and partial amputation. Even so, traditionalists still defend the use of the spear. An elderly man interviewed on television explains: "We prefer the spear because it's the traditional weapon for us Xhosas. We feel we must go back to our roots." (Robinson, 2002.)

A significant complicating factor is the delay between the development of complications and the time that the initiate seeks medical attention. Even if his life is in danger, it is considered to be a last resort for the initiate, the ikhankatha and the boy's family, as seeking medical help means that they have given up on preserving the cultural tradition. If a boy should die during initiation, little or nothing is said, and his family members will not get full details on how he died. It may happen that his family members simply get a message that they do not need to send him food any longer. In some cases his plate is brought home (Marck, 1997:337-360). His body is also not returned to his family.

\subsection{The amaXhosa: culture, tradition and values}

Culture gives people a general design for living and patterns for interpreting their reality. It gives people a sense of who they are, where they are going to and how they fit into society (Shaffer, 2007:248). For the purposes of this article, society and culture refer to aspects of the social environment that regulate human conduct, thus following the theory of adaptation where human behaviour occurs in a specific social environment. This view is evident in the 
words of a respondent: Umntu ngumntu ngabantu. The literal translation is: "To be human is to relate with others", and "One gets strength from one's relations with others".

In order to understand this ritual from the viewpoint of the Xhosa culture, one needs to understand the worldview of the Xhosa. Although there is diversity and underlying differences among traditional African cultures, Sow (1980:125) explains that there is a unity "that is evident in the realm of spirituality, as well as in behaviours manifested in everyday life". Humans form a whole with the cosmos, and are the point of departure and centre of the universe (Meyer et al., 1997:617). From this centre everything is understood and explained. Sow (1980:110) describes three realities which can be distinguished, namely the macro-, meso- and microcosmos.

The macrocosmos is the domain in which God is encountered, together with the ancestors and the spirits of specific, chosen people who have died. Everything the African person does is embedded in his/her religion. This religion focuses primarily on the community to which the individual belongs. This is closely bound up with the African person's collective functioning.

The mesocosmos, which is the spiritual domain, is the place where all conflict and events such as illness and death are explained. This is the domain of healers, priests and rainmakers, who influence and determine human behaviour. It is the level from which the dynamics of behaviour of African people, and specifically Xhosa people, should be understood (Mtuze, 2008:119). The outcome of a situation is often not attributed to an individual's behaviour, but to external agents outside the person. Because all behaviour and events are ascribed to external, supernatural beings or powers, individuals may therefore tend not to hold themselves responsible or accountable for their own behaviour (Mtuze, 2008:116). According to Malan (1989: 34-49), this implies that personal initiative in searching for solutions is repressed, since people see themselves as being at the mercy of supernatural beings and powers.

The microcosmos is the domain of the individual person in his/her every day, collective existence. The life of the individual is influenced by the macrocosmos and the mesocosmos. Rather than focusing on individuality, uniqueness and personal differences, the individual in the microcosmos has an ethos of sameness and commonality. In an interview Wole Soyinka, Nigerian-born poet, philosopher, playwright, political activist and Nobel Prize winner for 
literature in 1986, had the following to say about individualism and identity formation:

I think there is one principle, one essential morality of African society which we must bear in mind, and that is, the greatest morality is what makes the entire society survive ... I think the obsession with individual salvation is a very European thing. I am not aware that it occupies the minds of our people. (Soyinka, 1999:110.)

The individual identity is therefore developed collectively. Children learn from their parents and other important people what will be expected of them. For the Xhosa boy it is initiation, which serves as a passport to acceptance and respect in his community. An uninitiated man is an object of ridicule. An uncircumcised boy is regarded as unclean and as a person of whom no good can be expected. In the event that such a person marries, his marriage will remain stigmatised.

A summary of the attitudes of Xhosa women with whom Van Vuuren and De Jongh (1999:142-156) conducted interviews, follows:

Men are expected to present themselves for initiation because: it transforms them from boys to men, it changes them psychologically 'for the better'; an uninitiated man is disrespected and hence also his wife and children; other men will mock an uninitiated man; women in a community know exactly which men are not circumcised - 'there are rumours and the word is spread'; 'a Xhosa woman will not sleep with an inkwenkwe (uninitiated boy) even if he is fifty years old!'

It is not enough just to go through the rite to prove oneself as a man. If the boy has to seek medical help he may be rejected as someone who could not prove his masculinity. As explained, for the women in this study masculinity carries the meaning of being courageous, and bearing suffering over and above the general meaning of being a man.

Some see medical complications and death as a way of separating out those boys who were supposedly not fit to play the role of men in society. A traditional perception exists that some boys must die for the social good. In an interview with Meintjes (1998:50), Mazwai states: "It has been an accepted fact that often out of a group of boys who go to the mountain - one in ten would not return."

Chief Ngangomhlaba Matanzima's statement in the House of Traditional Leaders (Meintjes, 1998:50) supports this view: 
Many women die while giving birth as do initiates at circumcision schools - no problem. After all, circumcision is a custom that introduces boys to manhood. Those who die during circumcision would not have made it in life after all.

If they do survive the process, they attain a position as respected members of the community and personal independence. It is thought to rid one of carelessness and is perceived as the only way in which change can be brought about in a person. Thus circumcised is equated with trust, desire and respect. According to Pauw (1975:201) "initiation is a ladder to humanity (ubuntu) and respect".

The connectedness between individual, the environment and the spiritual world is a unifying aspect among the amaXhosa. When this is taken into account, it can be better understood why seeking medical attention would be a last resort for a boy and his family, why ritual taboos are avoided during this time, and why preserving the cultural tradition would sometimes be deemed to be more important than the boy's well-being. Unfortunately, this means that the best interests of children may not always be put first. The worldview, where the fate of a child is decided by external agents other than a parent or care-giver, implies that a parent may hesitate to take responsibility for matters concerning their children or children in their care. Women do not only have the right to be involved in any matter concerning their children's physical and emotional well-being, but as legal guardians under the law, are responsible to put their children's safety above any cultural custom or ritual. It is the author's view that children should be accepted and loved for who they are and an initiation ritual should never be a condition for respect and acceptance.

\section{Methodology}

The positivist approach was followed to conduct a survey (Neuman, 2000:110). A questionnaire was developed in order to establish the attitudes of a group of Xhosa women regarding their sons' rite of initiation. It consisted of 56 questions with Likert-scale response options. One open-ended question was set and was interpreted qualitatively. The rationale for the open-ended question was to offer participants the opportunity to express their opinion regarding initiation freely, and to share an experience they might have had regarding their son's initiation.

The following aspects were tested with the closed-ended questions: 
- Traditional initiation versus hospitalisation

- Reasons for medical complications

- Evaluating certain aspects of initiation as child abuse

- Importance of the custom for attaining manhood

- Involvement of women in the initiation rite

- Changes in behaviour of boys after initiation.

The questionnaire was administered to Life-Orientation students at the University of South Africa (UNISA). They were all teachers and lived mainly in the Eastern Cape. The questionnaires were sent to 800 students and 220 questionnaires were returned. Of the 220 questionnaires, 54 were completed by Xhosa women and were used for the research.

In addition to the questionnaire, an in-depth interview was conducted with one Xhosa woman, who was selected as a participant because she grew up in the Eastern Cape. She used to work in Frere Hospital in East London as a senior nurse, treating boys who were hospitalised after contracting sepsis during the ritual of initiation.

The respondents of the questionnaire remained anonymous and the participant who was interviewed will be called Tembi. Permission for the research was obtained from the Ethics Review Committee of the College of Human Sciences at UNISA. A special effort was made to present the qualitative data exactly as it was told by respondents, in order to produce authentic information and valid findings (McNiff \& Whitehead, 2009:75). Care was also taken to select respondents who shared enough background characteristics (Rihoux \& Ragin, 2009:20), such as that all respondents were women, all were Xhosaspeaking, and all had the same academic background.

\section{Results and discussion}

The questionnaire results showed that on the question of upholding cultural practice in spite of health risks, $57 \%$ of the respondents were of the opinion that circumcision should take place in hospital; and $31 \%$ felt that it should only take place in the bush according to the traditional Xhosa custom. Although the data indicate that the majority were in favour of circumcision in hospital, a conflict is evident, as $74,5 \%$ indicated that they believe a man can only become a 
respected member of society after traditional initiation. The following statements support this view:

At home, they will respect them and call them 'Banna'. If they didn't go, they will misuse manhood.

My son was attended by his grandfather because his father works in the city. I now believe my son is a real man.

My son knew that he would be nothing without undergoing this custom. I'm a Xhosa woman and feel very proud about it.

According to these views, traditional initiation or "initiation in the bush" is a condition for respect and value as a human being. This is also a clear condition for acceptance as person. Without traditional initiation, the implication is that a boy or man may be considered as having low moral values, for example that he could "misuse manhood" or "be nothing". An "all or nothing" attitude is evident here. However, the previously mentioned conflict in opinion is evident from the fact that half of the $74,5 \%$ who were in favour of traditional initiation, indicated that they considered certain parts of initiation as child abuse.

Regarding some people's view that medical complications experienced by the boys are normal in the course of life, $27,50 \%$ of the respondents agreed in favour of child abuse. One respondent said:

If my son would die at the bushes I would accept that as his way God created to take him back. I would not blame anyone. Phambili Ngolwaluko Iwama Xhosa ehlathini Nasezintabeni! (Forward with the initiation of Xhosas in the bushes and mountains!)

This view was supported by $40 \%$ of the respondents who felt that cultural customs are more important than an individual boy's emotional and physical welfare.

Regarding the complications experienced during initiation, $84 \%$ of the respondents felt that it is caused by a lack of knowledge on the part of the men who perform the procedure of circumcision, drunkenness at initiation sites, a lack of clean water, and the crowding of initiates into small spaces.

In the answers to the open-ended question various incidences were shared where mothers feared for the well-being of their children, but felt powerless to do anything: 
He must go but if he goes there and dies, he die and be buried there at the bushes by men only. No one whose going to tell you or inform you about the death of your son. Even your husband he can't tell you (Lisiko lakwe Xhosa ezasentabeni azithethwa) even to your wife.

Till the last day when they come back it's where by you gonna notice that my son is not there. Uuh! It's terrible, painful, traumatising.

I discovered that my son was staying there for three weeks without drinking water. I sent porridge and the senior boys brought it back and destroyed the walls of my lapa.

It was bad for me; I was worried about his health. I could not listen to radio news. I was scared. Whenever I hear news about a boy who died my heart could pump even faster. The day he came back I was happy; he was skinny and very pale. I would be very glad if this stupid custom could be abolished. It is causing a lot of pain for both the boy and parents.

Tembi explained:

It is not talked about to women in general. It is talked about in the community but women have got a limited knowledge of what happens there ... If the boy is sick there the mother doesn't know, if unless she is told. Even if she is told, if she wants him to go to the hospital, she is up against the men; even if there is an illness or a casualty she will not be told. After a week the men will bring the message that the boy can start to have food with salt, only then the mother learns that her son is getting better.

These accounts demonstrate women's fear for their children's lives, but also their fear of going against authority. This leaves them powerless and with a sense of betrayal, as their husbands are not even allowed to tell them when their sons died. Moreover, women who go against the men's authority may be punished, as one woman explains:

Women keep quiet and don't even say nothing about that and if they find you talking about this business, they take you straight to the tribal authority and punish you by claiming that you pay something e.g. to buy a cow.

One woman said that she planned to be involved in the decision making of her son's initiation: 
As a mother I will say something because I will be the one who will be responsible when he is there. And I cannot trust man alone about my child.

One of the purposes of the initiation ritual is to teach boys about proper manhood. Where manhood generally means to have the chronological status of a man that follows that of a boy, Tembi refers here to men earning their community's respect by taking part in the ritual of initiation, by acting courageously and by bearing suffering.

She explains:

To start with, when they come home, they cover their face which is a sign of respect; they go into a special room to get dressed. After that they are taken out of there to the kraal. All the men are then asked to talk to them, they are advised, in terms of, now they are men. These are the things that a man does not do, this is how a man behaves. Now that is a very special part because you cannot get just any drug addict to talk to them, you get someone whom the boy can look up to, this is very personal; you get someone who is respected in the community.

Although Tembi's words show that the purpose of initiation is inherently good, data from the questionnaire show that the outcomes of initiation often do not serve this special and unique purpose.

\section{Findings}

On the whole, the findings of the research data illustrated the inner conflict and differences between Xhosa women regarding their sons' rite of initiation. In research conducted by Steyn (1987:163-174) among Xhosa women, $98,5 \%$ of the respondents felt that the traditional ritual of initiation should carry on as before. The current findings indicate a change of view. Considerably fewer $(31 \%)$ of the women felt that the whole initiation ritual should take place in the bush in the traditional way, with no medical support or women present.

Although circumcision in hospital has become more acceptable according to the results of this study, the majority of respondents $(74,5 \%)$ still indicated that they believe that a man can only become a respected member of society after initiation in the traditional way. This incongruence in the respondents' viewpoints may indicate a state of transition where the Xhosa woman may be caught in a 
struggle between her allegiance to her traditional customs, and her need to protect her children.

A conflict also exists in the sense that half of the women who felt initiation is necessary for a man to become a respected member of society (74\%), also regarded certain aspects of initiation as child abuse. Except for a few women who became involved in the drive against the traditional custom, the respondents still mostly accepted their relatively passive role that entails taking part in preparations and celebrations, but with no real involvement in decision making.

\section{Conclusions}

The aim of this article was to illustrate the conflict that exists in some Xhosa women regarding their views on certain aspects of the cultural rite of initiation. The study granted them the opportunity to express their opinion in a safe environment. Breaking the taboo of silence seemed to be a relief for most of the respondents, in that it helped to open up the matter for communication. With that came the advantage of sharing pride in a communal custom, but also the pain that might have been hidden for a long time.

The worldview where the fate of a child is decided by external agents outside a parent or caregiver implies that Xhosa parents do not always put the best interests of children first. The author's point of view is that parents should take responsibility for matters concerning their children or children in their care. Not only do women have the right to be involved in any matter concerning their children's physical and emotional well-being, but as legal guardians under the law, they are responsible for putting their children's safety above any cultural custom or ritual. The author's stance is not that cultural practices among the amaXhosa should be abolished, as these serve to build the identity of the individual within the group. Instead, all parties concerned - that is Xhosa people and professionals in helping professions in this case - should agree that the physical and emotional safety of children is the most important matter.

Although there is a large difference between the views of Xhosa women that were reported on in the 1980s and the views of Xhosa women in this research study, one should be careful not to generalise these results, as various conflicts in their thinking were evident. However, there seems to be an awareness of the dangers of initiation and a need for Xhosa women to play a role in preventing malpractice during this cultural ritual. 
The research reported on in this article only touched on a few aspects of cultural initiation, with the main focus being on the physical and emotional safety of the boys, and the role and attitude of the women involved. Future research needs to look at the position of children in different contexts, where they internalise their cultural identity, build their self-concept on it and live according to it - even though it may sometimes be to their physical and emotional detriment.

\section{List of references}

ANON. 2010a. More initiates die. Pretoria News: 2, 29 Jun.

ANON. 2010b. Minister closes initiation school in Pondoland. Pretoria News: 4, 13 Jul.

BERK, L.E. 2009. Child development. Boston: Pearson Education.

BONGELA, K.S. 2001. Isihlonipho among AmaXhosa. Pretoria: UNISA. (D. Lit. et Phil. thesis.)

BOTTOMAN, B. 2006. The experience of indigenous circumcision by newly initiated Xhosa men in East London in the Eastern Cape Province. Pretoria: UNISA. (M.Ed. dissertation.)

DE LA HARPE, R. 2002. The making of men. Getaway, 14(6):70-71, 73-74.

GEISLER, G. 1997. Women are women or how to please your husband: initiation ceremonies and the politics of "tradition" in Southern Africa. African Anthropology, 4(1):92-127.

HUISMAN, P. 2009. Boy taking parents to court over constitutional rights. The Times: 1, 14 Aug.

KRETZMAN, S. 2000. Equal rites for circumcision initiates. Land and rural digest, 19(1):27-29.

LODEWIJCKX, H.F.M. \& SYROIT, J.E.M.M. 1997. Severity of initiation revisited: does severity increase attractiveness? European journal of social psychology, 27(3):275-300.

MAGUBANE, P. 1998. Vanishing cultures of South-Africa. London: Struik.

MALAN, J.S. 1989. Ontwikkelingsperspektief vanuit Kognitiewe Antropologie. South African journal of ethnology, 12(2):34-49.

MARCK, J. 1997. Aspects of male circumcision in subequatorial African culture history. Health transition review, 7(1):337-360.

MCNIFF, J. \& WHITEHEAD, J. 2009. Doing and writing action research. Los Angeles: Sage.

MEINTJES, G. 1998. Manhood at a price: socio-medical perspectives on Xhosa traditional circumcision. Grahamstown: Rhodes University. (M.Ed. dissertation.)

MEYER, W.F., MOORE, C. \& VILJOEN, H.G. 1997. Personology: from individual to ecosystem. Johannesburg: Heinemann.

MNCUBE, F.S.M. 1987. Hlonipha language as found among the Zulu-Xhosa women. Johannesburg: University of the Witwatersrand. (M.Ed. dissertation.)

MTUZE, P.T. 2008. Bishop Dr S Dwane and the rise of Xhosa spirituality in the Ethiopian Episcopal Church. Pretoria: UNISA. (D. Theol. thesis.)

NEUMAN, W.L. 2000. Social research methods: qualitative and quantitative approaches. Boston: Allyn \& Bacon. 
NGXAMNGXA, A.N.N. 1968. The function of circumcision among the Xhosaspeakers. Pretoria: UNISA. (Hons. B.A. dissertation.)

NTOMBANA, L. 2009. Xhosa male initiation and teaching of moral values: an exploration of the role of traditional guardians in teaching the initiates, in Indilinga. African journal of indigenous knowledge systems, 8(1):73-84.

PAUW, B.A. 1975. Christianity and the Xhosa tradition. Cape Town: Oxford University Press.

RIHOUX, B. \& RAGIN, C.C. 2009. Configurational comparative methods. Thousand Oaks: Sage.

ROBINSON, F. 2002. Fokus met Freek. SABC: 3, 20 Jun.

SHAFFER, D.R. Developmental psychology. 2007. Belmont: Thomson Higher Education.

SOW, I. 1980. Anthropological structures of madness in black Africa. New York: International Universities Press.

SOYINKA, W. 1999. The burden of memory, the muse of forgiveness. New York: Oxford University Press.

STEYN, H.P. 1987. Inisiasie en die stedelike milieu. Etnologie, 10(4):163-174.

TENGE, S. 2006. Xhosa teenage boys' experiences during the period prior to circumcision. Pretoria: UNISA. (M.A. dissertation.)

VAN GENNEP, A. 1960. The rites of passage. London: Routledge \& Kegan Paul.

VAN VUUREN, C.J. \& DE JONGH, M. 1999. Rituals of manhood in South Africa: circumcision at the cutting edge of critical intervention. South African journal of ethnology, 22(4):142-156.

WALQUE, D. 2006. Who gets AIDS and how? Washington: World Bank, Development and Research Group.

\section{Key concepts:}

initiation

Xhosa male initiation

Xhosa rites of manhood

Xhosa tradition

Xhosa women's views regarding initiation of boys

\section{Kernbegrippe:}

inisiasie

Xhosamans, inisiasie van

Xhosarituele vir mans

Xhosatradisie

Xhosavroue, opinie rakende inisiasie van seuns 
